\title{
ON THE ORIGIN OF GOTHIC ULBANDUS 'CAMEL'
}

Great are the merits of Bojan Čop in Hittite lexicography and etymology. Glancing merely at volume 3 of the Hittite Etymological Dictionary, the latest to leave my workshop, his ideas have either provided the etyma or pointed the way to the interpretation of such important items as halkuessar, halluwa-, halzai-, hattalkesna-, hazzila-,

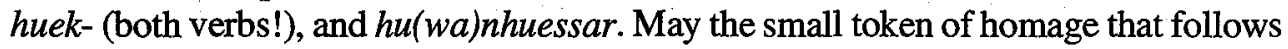
be worthy of his endeavors!

The Semitic word for 'camel', exemplified by Hebrew gãmãl, makes its Greek debut as Kó $\mu \eta \lambda ం \varsigma$ in Aeschylus (Hiketides 285); via Latin camellus it has conquered the modern west. In the other direction it appears, with some apparent interference from the verb krámate 'stride', as Sanskrit kramela-, supplementing the old Vedic term úștra-, of Indo-Iranian attestation (cf. Avestan Zara $\theta-u$ štra-, either 'Old-camel' or 'Camel-driver'). Unlike such relatively neat and short terms, the ungainliness of the beast is more picturesquely expressed by the designations for it in Germanic, Slavic, and Baltic. Starting with Gothic ulbandus, the Germanic attestations are ON ulfalde, OE olfend, OS olbundeo, and OHG olbento. The Slavic forms (OCS velïbodŭ, Russian verbljúd, Polish wielbład) appear to have been folk-etymologically twisted in the direction of velii 'big, great', whereas the Baltic variants (OPr. weloblundis, misrendered as 'mule' by the Elbing Vocabulary [line 437]; Lith. velbliúdas) are patent borrowings from Slavic.

Received wisdom ${ }^{1}$ presumes for ulbandus and company "same origin" as $\mathrm{OE}$ elpend, OHG elafant, i.e. 'elephant' borrowed from Latin elephas (elephant-) which

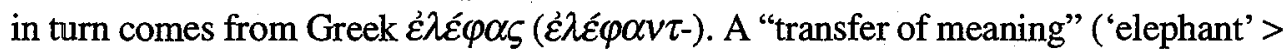
'camel') is assumed, but the best parallel produced is a dialectal Arabic bil for 'camel', allegedly a variant of the old word for 'elephant' which ranges from Akk. pïru or pīlu 'elephant' to Old Persian piru- 'ivory' to Aramaic and Persian pill, Sanskrit (late) pîlú-, Arabic fil, and Old Norse fill 'elephant' ${ }^{2}$. Even this is no parallel at all', for the Ger-

1 E.g. W.P. Lehmann's recasting of S. Feist's Gothic Etymological Dictionary (Leiden, 1986), 375. In the same vein still C. Sandoz, Latomus 48 (1989), 753-764.

2 Also $\pi \imath \rho i \sigma \sigma \alpha \varsigma$ 'elephant' (Hesychius), perhaps 'elephant cow' like Akk. pīrāti or Skt. pillakā.

3 Weaker still is the alleged derivation of Russian slon 'elephant' from Turkic a(r)slan 'lion'; Russian Ruslán is well taken as such in origin, but slon is better traced back to Austroasiatic words for 'elephant' (cf. T. Gamkrelidze and V.V. Ivanov, Indoevropejskij jazyk $i$ indoevropejcy [Tbilisi, 1984], 524-525). Not so, however, Tocharian B oñkolmo (A on̄kaläm) 'elephant', whose source V.V. Ivanov (Etimologija 1980 [Moskva, 1982], 166) also surmised in Austroasiatic. In oñkolmo may lurk rather an Indo-European 
manic words for 'camel' are no stray dialectal semantic deviates but engrained across early Germanic before the intrusion of the Greco-Latin word for 'elephant'. One would have to assume instead that some remote proto-designation existed from which evolved semantically 'elephant' on the one hand, 'camel' on the other. But the earliest attainable meaning of $\dot{\varepsilon} \lambda \dot{\varepsilon} \varphi \alpha \nu \tau$ - is rather 'ivory': $e$-re-pa-(te-) is well attested as an ornamental material in Mycenaean Greek, but the beast itself was unknown in Europe, being mentioned first for Ethiopia and Libya by Herodotus $(3.114,4.191)$, and described for India by Aristotle (Hist. Anim. 2). Syro-Phoenician sources of Euphratic ivory were accessible to the Greeks earlier than the animal made a mental imprint, even as in Italy Punic mediation produced the ebur (from a Hamitic term seen in Egypt. $3 b w$ 'elephant' and 'ivory') ${ }^{4}$ way before the Luca bos or bos Luca that was militarily introduced to Italy ahead of Hannibal by Pyrrhus in 280 b.c.e. and later described in lumbering detail by Lucretius (5:1301-2). Clearly, therefore, $\dot{\varepsilon} \lambda \hat{\varepsilon} \varphi \alpha \nu \tau$ - entered Greek as a term for ivory, rather than as a zoonym; only later did metonymy include the animal source of the product 5 .

Additionally, the discovery of lahpa- as the Hittite term for 'ivory' (matching Akk. šinnu at Ugarit) ${ }^{6}$ has clarified the sources of $\dot{\varepsilon} \lambda \dot{\varepsilon} \varphi \alpha \nu \tau$-. It did not stop Gamkrelidze and Ivanov from Indo-European etymologizing (still drawing in ulbandus, etc.) ${ }^{7}$, and may have led Laroche ${ }^{8}$ to overstress similarities to the Semitic terms for 'ox'

compound 'snake-handed' (cf. Lucretius 2:538 anguimanos elephantos, 5:1301 boves Lucas ... anguimanos), made up of cognates of Lat. anguis and palma (OIr. läm 'hand'), i.e. *angh ${ }^{w} i$-plAmön. This makes more sense than A.J. Van Windekens' *anq-olmō(n) 'bent-being' (i.e. with curved trunk; Le tokharien 1 [Louvain, 1976], 337) or J.E. Rasmussen's * $h_{2 m} m b h i-k^{w} I_{1} h_{1} m_{a} h_{2}$ (allegedly elephant as

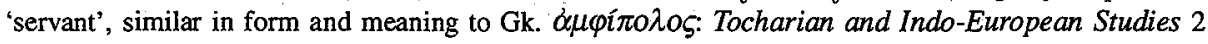
[1988] 166-183; Acta Linguistica Hafniensia 21 [1988], 92). Cf. J. Puhvel, HS 106.

4 Also in the Hebrew hapax šen-ha-bbīm 'tooth of elephants' (usually simply šên 'tooth' or qarnōt šên 'horns of tooth' for 'ivory'). On the increasingly dubious relevance of Skt. ibha- 'elephant' see M. Mayrhofer, Etymologisches Wörterbuch des Altindoarischen (Heidelberg, 1988), 194.

5 In languages closer to elephant habitats the distinction was clearer from the start: Vedic for 'elephant' was mrgó hastín- 'beast with hand', and 'ivory' was Skt. hastidantam. Sumerian had am.si 'elephant' (am sign seemingly made up of gud + kur 'mountain ox', si 'horn'; thus 'horned mountain ox') and ka+ud am.si 'ivory' (literally 'tooth of elephant', like Akk. šinnu [pīri]). In modern languages such derivation has reasserted itself (e.g. German elfenbein, Danish filsben).

6 See Chicago Hittite Dictionary 3.1 (1980), 12-13; J. Tischler, Hethitisches etymologisches Glossar 2 (1990), 14-15. J.-C. Billigmeier (A Linguistic Happening in Memory of Ben Schwartz [Louvain, 1988], 321-331) suggested that Lat. Luca bos is in reality lucabos, a late Asianic ("neo-Hittite", perhaps Lycian) survival of lahpa- (presumably meaning 'elephant' in addition to 'ivory'), and that bos Luca was a Roman folk interpretation. This hunch puts a lot of faith in Pyrrhus' Hellenistic army employing eastern mahouts who instantly taught their exotic term for 'elephant' to the Italic natives under battle conditions. More probably bos Luca is a genuine "nativism", like Sumerian am.si (see fn. 5); cf. R. Arena, Rivista difilologia 116 (1988), 185-197.

7 Loc.cit. in fn. 3. Lehmann (see fn. 1) erroneously claims that Th. von Grienberger (SÖAW 142/8 [1900], 225) denied an early relationship of ulbandus and elephant-; G. did exactly the opposite, postulating an Indo-European prototype of both. 
(Akk. alpu, etc.), but it established a likely term for 'ivory' in the Syrian-AnatolianHelladic orbit of the latter half of the second millennium, one that has no plausible Indo-European origin or connection with 'camel' words such as Gothic ulbandus.

What then of the latter? Otto Schrader ${ }^{9}$ had a thought on ulbandus which deserves to be quoted: "An einem Zusammenhang mit lateinisch elephantus ist schwerlich zu denken. Vielleicht gehört got. ulbandus wie andere undeutbare Kulturwörter dieser Sprache (z.B. peikabagms 'Dattelpalme', smakka 'Feige', baírabagms 'Maulbeerbaum') zu dem Sprachgut, das die Goten nach ihrer Ankunft am Schwarzen Meer von ihren Beutezügen in Kleinasien heimbrachten".

This suggestion may have been an inspired one, for it appears that Hittite supplies what may be either a borrowing source or a cognate for ulbandus. There is the word huwalpant- which means 'humpback', as in the teratogeny lists of birth omina (KBo XIII 34 IV 3-4 takku SAL-za hāsi n-as [...] huwalpanza 'if a woman gives birth and [the baby] [is] a humpback...'). There is further the derived noun $h u($ wa)lpanzina-, hulpanzana- 'hump, protuberance, embossment', both in an anatomical sense (KBo XIII 31 I 6) and referring to metal ornamentation (e.g. KUB XLII 69 Vs. 25-26 GÍR URUHatta arahzan[da... [...] 30 hulpanzanas GUŠ[KIN 'swords of Hatti, all around

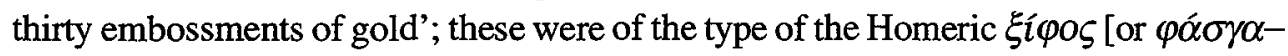
vov] $\alpha \rho \gamma \nu \rho o ́ \eta \lambda o v$ 'silver-studded sword'). From a denominative verb hulpanzinai'emboss' there exist both Hittite and Luwian-type passive participles, e.g. $K B o$ II 1 I 381 URUDUGIR TA GUŠKIN $h \bar{u} w a l<p a>z i n a n$ 'one bronze dagger embossed with gold'; KBo XX 47, 11-12 nu-za LUGAL-us ... [hu]lpanzinanda wasiyazi 'the king dons embossed regalia'; KUB XII 1 IV 34 GU]ŠKIN hulpanzinaimes '[shoes] embossed with gold' 10 .

The external similarities of $h u(w a) l p a n t-$ and $u l b a n d-$ require little comment. The Gothic $u$-stem is unexpected; considering the Luwian elements such as the participle hulpanzinaima-, one would have looked for an $i$ - stem *hu(wa)lpanti- as perhaps underlying the derivative hulpanzina-. The camel being called 'humpback' is self-explanatory. As Indo-European reconstruction can serve * $H w l b(h) o$-related etymologically to Skt. úlbam, Lat. volba 'uterus, womb', and perhaps to Hittite huelpi- 'newborn'. The question whether ulbandus is a borrowing from Anatolian into early Germanic or cognate Indo-European remains open; perhaps the typically Anatolian - nt- suffix tends to tilt the balance in favor of borrowing, thus giving Schrader's intuition its full due.

8 Revue de philologie 39 (1965), 56-59; cf. E. Masson, Recherches sur les plus anciens emprunts sémitiques en grec (Paris, 1967), 80-83.

9 Reallexikon der indogermanischen Altertumskunde, $2^{\text {nd }}$ ed. (Berlin, 1917-29), 1:553.

10 For full data, see J. Puhvel, Hittite Etymological Dictionary 3 (Berlin, 1991), 424-426. 


\section{Povzetek \\ IZVOR GOTSKEGA ULBANDUS 'KAMELA'}

Slovanska in germanska beseda za kamelo (npr. gotsko ulbandus in starocerkvenoslovansko velibọdŭ) se navadno povezujeta $\mathrm{z}$ besedo elefant 'sIon' (grško é̉ $\bar{\varepsilon} \varphi \alpha \nu \tau$-). Ta povezava je sporna: $\varepsilon \dot{\lambda} \hat{\varepsilon} \varphi \alpha v \tau$ - spada $\mathrm{k}$ hetitskemu lahpa- 'slonova kost', vtem ko je sorodnik besede ulbandus hetitsko huwalpant- 'grbavec' in njegove izpeljanke s pomenom 'grba' ali 'izboklina'. 